\title{
A tobozmirigy-csecsemőmirigy rendszer szerepe az autoimmunitás, öregedés és élettartam szabályozásában
}

\author{
Csaba György dr. \\ Semmelweis Egyetem, Általános Orvostudományi Kar, Genetikai, Sejt- és Immunbiológiai Intézet, Budapest
}

\begin{abstract}
A csecsemőmirigy (thymus) immunoendokrin szerv, amelynek endokrin elemei által termelt hormonok elsősorban a szerv saját immunelemeire hatnak. Az immunrendszerben központi szerepet tölt be, újszülöttkori eltávolítása az immunrendszer és az egész szervezet összeomlásával jár. A thymus dajkasejtjei a csontvelő-eredetű lymphocytákat szelektálják és a sajátot idegenként felismerő (autoreaktív) sejteket még a thymusban elpusztítják, illetve az ugyancsak thymuseredetű Treg-sejtek a periférián elnyomják. A szerv involúciója már születés után elkezdődik, de csak a serdülőkor vége felé válik kifejezetté, mert addig az egyidejű fejlődési folyamatok túlkompenzálják. A pubertás utáni involúció inkább megengedi az autoreaktív sejtek életben maradását, felszaporodását és fokozott múködését, ami fokozatosan koptatja, pusztítja a szervezet sejtjeit és sejt közötti állományát, ezzel előidézi az öregedés jelenségét. Az autoreaktív sejtek további fokozott múködése okozza az autoimmun betegségeket és vezet a természetes halálhoz is. A thymus involúciója tehát nem a szervezet általános sorvadásának részjelensége, hanem annak okozója, ami az élettartam-pacemaker funkcióban mutatkozik meg. Az öregedés tehát felfogható egy thymusvezérelt lassú autoimmun folyamatnak. A tobozmirigy újszülöttkori eltávolítása a thymus degradációjához, az immunrendszer összeomlásához és a szervezet sorvadásához (wasting disease) vezet. A mirigy felnőttkori involúciója a thymus involúciójával párhuzamosan fut, így a két szerv funkcionális egységet képez. Valószínú, hogy a corpus pineale felelős a thymus involúciójáért, ezáltal annak élettartam-meghatározó szerepéért is. Az ismertetett adatok nem bizonyítják a tobozmirigy-csecsemőmirigy rendszer kizárólagos szerepét az öregedés és élettartam meghatározásában, csak felhívják a figyelmet arra, hogy ez a rendszer önmagában is alkalmas a feladat elvégzésére. Orv. Hetil., 2016, 157(27), 1065-1070.
\end{abstract}

Kulcsszavak: tobozmirigy, csecsemőmirigy, öregedés, élettartam, immunitás, autoimmun betegségek, immunszelekció, immunöregedés

\section{The role of the pineal-thymus system in the regulation of autoimmunity, aging and lifespan}

Thymus is an immunoendocrine organ, the hormones of which mainly influence its own lymphatic elements. It has a central role in the immune system, the neonatal removal causes the collapse of immune system and the whole organism. The thymic nurse cells select the bone marrow originated lymphocytes and destroy the autoreactive ones, while thymus originated Treg cells suppress the autoreactive cells in the periphery. The involution of the organ starts after birth, however, this truly happens in the end of puberty only, as before this it is overcompensated by developmental processes. From the end of adolescence the involution allows the life, proliferation and enhanced functioning of some autoreactive cells, which gradually wear down the cells and intercellular materials, causing the aging. The enhanced and mass function of autoreactive cells lead to the autoimmune diseases and natural death. This means that the involution of thymus is not a part of the organismic involution, but an originator of it, which is manifested in the lifespan-pacemaker function. In this case aging can be comprehended as a thymus-commanded slow autoimmune process. The neonatal removal of pineal gland leads to the complete destruction of the thymus and the crashing down of the immune system, as well as to wasting disease. The involution of the pineal and thymus runs parallel, because the two organs form a functional unit. It is probable that the pineal gland is responsible for the involution of thymus and also regulates its lifespan determining role. The data reviewed do not prove the exclusive role of pineal-thymus system in the regulation of aging and lifespan, however, calls attention to the suitability of solving this problem alone.

Keywords: pineal gland, thymus, aging, lifespan, immunity, autoimmune diseases, immune selection, immonosenescence

Csaba, G. [The role of the pineal-thymus system in the regulation of autoimmunity, aging and lifespan]. Orv. Hetil., 2016, 157(27), 1065-1070.

(Beérkezett: 2016. március 29.; elfogadva: 2016. április 26.) 


\section{Rövidítések}

$\mathrm{ACTH}=$ a hipofízis adrenokortikotrop hormonja; $\mathrm{CD}=1 \mathrm{ym}-$ phocyták sejtfelszíni markerei, melyek jelzik a sejt érési állapotát; $\mathrm{MHC}=$ major histocompatibility complex, a sejtek saját vagy idegen voltának felismerését szolgáló molekula-komplexek; SCN = suprachiasmaticus mag az agyban; Treg = szabályozó T-lymphocyták, alapvető szerepük van az immuntolerancia fenntartásában és az autoimmunitás elleni védekezésben (szuppresszorok); TSH $=$ a hipofízis tireotrop hormonja

$\mathrm{Az}$ endokrin mirigyek által képviselt rendszer feltérképezése a múlt század harmincas éveiben befejeződött, és ismertté váltak azok a hormonok, amelyek az emberi élet szabályozásában alapvető szerepet játszanak. Két „sötét ló” azonban maradt, amelyek hormonja és a szervezetben betöltött szabályozószerepe ismeretlen volt. E két mirigy a tobozmirigy (corpus pineale) és a csecsemőmirigy (thymus).

A tobozmirigy már az ókorban is ismert volt. Hérophilosz görög anatómus az időszámításunk előtti IV. században a gondolatok közvetítőjének tartotta a mentális és fizikai birodalmak között. Később, az időszámításunk utáni II. században Galénosz a lélek székhelyét látta benne a szív fölötti elhelyezkedése miatt, és ez a hit tartósan fennmaradt, még Descartes is annak hitte. A korai latin anatómusok mestermirigyként tartották számon, amely ellenőrzi a többi endokrin mirigyet, beleértve a hipofízist is. Csak 1958-ban ismerte fel a hormonját Aaron Lerner, egy amerikai bőrgyógyász, aki azt melatoninnak nevezte el, mert kísérleteiben békák bőrének melanocytáit befolyásolta. A szerotoninból transzformálódott melatoninról később kiderült, hogy emlősökben, így emberben is a cirkadiális ritmus, az álom-ébrenlét fázisok fenntartásáért felelős, de számos egyéb, nem kevésbé fontos hatása is van. Így az ecto-ento dermalis eredetû endokrin mirigyek szabályozója [1], és jelentős az antioxidáns hatása, amellyel részben gátolja az oxidatív molekulák megjelenését, részben elősegíti azok lebontását, valamint részt vesz a szervezet homeosztázisának fenntartásában, az immunvédekezésben, befolyásolja a reproduktív szervek múködését férfiban és nőben egyaránt $[2,3]$.

A csecsemőmirigy ugyancsak ismert volt már az ókorban is. Orvosi nevét valószínúleg Galénosz adta, feltételezik, hogy azért, mert egy csokor kakukkfüre (thymos) hasonlít. Azt is felismerte, hogy a szerv súlya az életkorral változik, amit késóbbi vizsgálatok is igazoltak. Vesalius a XVII. században egy mellkasi párnának hitte, amelynek funkciója az életfontos mellkasi szervek (szív, tüdő) védelme lenne. Később ez a tévhit egy másik tévhitre módosult, a légzôszervek szabályozójának tartották. A XVIII. század vége felé igazolták Galénosz korai észlelését a szerv életkorral csökkenő súlyáról, és ekkor a nyirokszervek közé sorolták. Még később endokrin szervnek tartották, amelynek azonban sem hormonját, sem funkcióját nem ismerték. Csak 1961-ben távolította el a thymust Jacques Miller újszülött egérból [4], aminek hatására az immunrendszer összeomlott, sorvadásos szind- róma (wasting disease) lépett fel, miközben eltúntek a később T-lymphocytáknak nevezett sejtek. Ettől kezdve a thymust az immunrendszer centrális szervének tekintjük és megindult azon hormonok keresése is, amelyek a thymus hámsejtjeiben termelődve a nyirokelemek sorsát befolyásolják. Nagyon sok ilyen „hormont” állítottak és ma is állítanak elő, azonban mindössze négy állta ki az idők próbáját, azaz bizonyult valóban hatásosnak. Ezek a timozin, a timulin, a timopoetin (timopentin) és a thymus humorális faktor (THF). Ezek mindegyike befolyásolja a lymphocyták sorsát (fejlődésüket, pusztulásukat, migrációjukat, hatásukat) és némi egyéb (thymuson kívüli) hormonális hatással is rendelkeznek, ez utóbbi azonban nem jelentős. A thymusban vannak (szintetizálódnak, tárolódnak, kiválasztódnak) egyéb, elsősorban más endokrin mirigyekre jellemző hormonok is (inzulin, ACTH, TSH, trijód-tironin, szerotonin, hisztamin, melatonin stb.), amelyeknek sejtes transzportja is megtörténik [5-7]. Azáltal, hogy a thymus endokrin és immunfunkciót is betölt, joggal sorolható tehát mindkét szervrendszerbe, és ebből a szempontból egyedülálló az emlősszervezetben. Ugyancsak egyedülálló abból a szempontból is, hogy endokrin termékei elsősorban a szerven belül, illetve a szerv által kibocsátott sejteken hatnak.

Nem látszik véletlennek, hogy az említett két mirigy funkciójának, illetve hormonjának felismerése a rendszer feltérképezésekor a végére maradt. Ezek a funkciók ugyanis kevésbé konkrétak, mint például az inzuliné, tiroxiné vagy adrenaliné. Ugyanakkor jelentőségükben nem maradnak el azok mögött, sőt - tekintetbe véve egész rendszereket befolyásoló képességüket (napi ritmus, immunitás) - meg is haladják azokét.

Ahhoz, hogy a thymus autoimmunitásban, öregedésben és élettartam-szabályozásban játszott szerepe érthető legyen, meg kell ismerkedni múködésével, de csak azokat a területeket tárgyaljuk részletesen, amelyek ebból a szempontból mai tudásunk szerint lényegesek és csak olyan mélységben, ami a tárgy megértéséhez szükséges.

\section{A thymus immunszelekciós múködése}

A saját és idegen felismerésében alapvető szerepet játszanak a lymphocyták, amelyeket Miller kísérletei óta két fó csoportba sorolunk: B- (mint bursa Fabricii-eredetú) sejtekre és T- (mint thymuseredetû́) sejtekre. A meghatározás emberi vonatkozásban így nem pontos, mert egyrészt az embernek nincs bursája, másrészt emberben minden lymphocyta a csontvelőben termelődik, tehát a későbbi T-sejtek is, amelyek innen kerülnek a thymusba. E sejtek között vannak olyanok, amelyek a saját sejteket, szöveteket is idegennek ismernék fel és elpusztítanák, míg mások csak az idegen ellen termelnének immunanyagokat. Az autoreaktív immunsejtek a thymusban kapnak olyan jelzést, amely miatt még itt öngyilkosságot követnek el (apoptózis), vagy ha mégis kijutnak a perifé- 
riára, ott pusztulnak el. A csontvelóből a thymusba bejutó lymphoid sejtek 95\%-a semmisül meg, és csak 5\% nem kapja meg a „halálos csókot” (markert), amely a véget jelenti [8].

A saját és idegen sejteket ellenségként felismerő sejtek szelekciójában alapvető szerepet játszanak a dajkasejtek. Ezek a thymus hámelemeihez tartozó nagy sejtek, amelyek jelen vannak a szerv kéreg- és velőállományában egyaránt [9], felismerik és bekebelezik az autoreaktív és idegenfelismerő lymphocyták előalakjait és a plazmamembránból leváló vesiculumokban halmozzák fel azokat, egy-egy dajkasejt akár 50-100-at is. A dajkasejtekben ezek az éretlen sejtek még szaporodni is tudnak [10], miközben tovább differenciálódnak, azonban az autoreaktív T-lymphocyták túlnyomó többsége (mintegy 98\%-a) elpusztul (negatív szelekció apoptózissal) és csak a maradék jut ki a perifériára az idegenfelismerő lymphocytákkal (pozitív szelekció) együtt. A perifériára kijutó autoreaktív T-sejteket az ugyancsak a thymusban fejlődő hosszú életú (úgynevezett természetes) regulátor (Treg-) sejtek ismerik fel, és bár nem ölik meg, gátolják a funkciókban (szuppresszor T-sejtek) [11]. A dajkasejtek felismerik és elpusztítják a degenerált T-lymphocytákat is [12], majd mind az autoreaktív, mind a degenerált T-lymphocytákat átadják a macrophagoknak, amelyek megemésztik azokat. Elvileg csak az ép, a sajátot idegenként fel nem ismerő T-lymphocyta hagyhatja el a thymust, ami mégis kijut hibásan, az a selejt, és a Tregsejteknek ezek kordában tartása a feladata.

Már Medawar Nobel-díjjal elismert kísérleteiből [13] ismert volt, hogy a szervezet életre szólóan toleráns azokkal a fehérjékkel szemben, amelyek a magzati korban jelen vannak, tehát az egyeddel együtt születnek. Ezek a fehérjék megjelennek a thymusban (saját antigén-MHCkomplexek), és a dajkasejtek ezekhez viszonyítva végzik el a negatív vagy pozitív szelekciót. A Treg-sejtek is a thymusban fejlődnek (CD25(+)CD4(+) T-sejtek) és innen kerülnek a perifériára, ahol biztosítják a veleszületett tolerancia fenntartását. Ami nem jelenik meg a thymusban, azt az immunrendszer idegennek tekinti (akár a szervezeten belïl keletkezett, akár kiviulröl hatolt be) és igyekszik elpusztitani. A sajátnak tekintendő fehérjék megjelenítését (prezentációját) a velőállomány sejtjei végzik el.

\section{A thymus involúciója}

Mint már Galénosz megfigyelte, a thymus terjedelme és súlya az életkorral változik. Maximális súlya átlagosan 37 gramm, és ez 75 éves korra 6 grammra csökken. A súlyváltozással párhuzamosan minőségi változások is történnek: az aktív parenchyma és lymphoid elemek helyét fokozatosan zsírszövet foglalja el. A szerv involúciójáról a késői pubertástól kezdve beszélünk, mert ilyenkor válik feltünővé, ugyanakkor tudjuk, hogy az említett elemek csökkenése már a 9 hónapos csecsemőben megfigyelhetô. A nemi hormonok fokozott megjelenésével a serdülőkorban az involúció felgyorsul (ezért válik feltűnővé), és 25-40 év között eléri az évi 3-5\%-ot, majd a továbbiakban lassul, de ilyenkor sem kevesebb évi 1\%-nál. Bizonyos tényezők - mint terhesség vagy intenzív krónikus stressz - hatására újra felgyorsul a folyamat [12]. Természetesen a sebesség és a mérték egyénektől függően, bizonyos határok között változó. A thymus involúciójában a teljes szerv részt vesz, azaz a stroma, a hámelemek és a lymphoid elemek egyaránt csökkennek. Mivel a thymus felelős a T-sejt-populáció kibocsátásáért, szelekciójáért, sőt a B-sejtek múködésébe is ezáltal beleszól [14], involúciója jelentôs változásokat hoz létre a periférián is. Csökken a naiv T-sejtek száma és aránya a B-sejtekhez viszonyítva, mivel utóbbiak mennyisége a periférián relatíve stabil. A thymus endokrin múködése, hormontermelése is változik minőségileg és mennyiségileg egyaránt, ami kihat immunológiai tevékenységére is. Mivel a szerv egyéb hormonok (például inzulin, trijód-tironin, szerotonin stb.) termelője és célpontja egyaránt, az involúció széles endokrin körben is megnyilvánul. A thymus öregedésével epigenetikai változások is bekövetkeznek, mert a gének metilációs mintázata is átalakul, lehetőséget teremtve bizonyos, addig gátolt funkciók expressziójának vagy múködő funkciók lezáródásának [15, 16].

\section{Involúciós modellek és mesterséges beavatkozások}

Mint ezt Miller már említett kísérletei mutatták, a thymus postnatalis eltávolítása az egész immunrendszer összeomlásához és wasting disease-hez vezet. A 3 napos korban egérben végzett thymectomia szervspecifikus autoimmun betegségeket vált ki [17], és autoantitestek, valamint T-sejtes infiltráció is kimutatható [18]. A felnőttkori thymectomia, mint a totális involúció modellje, messze nem ilyen drasztikus hatású. A lymphocyták mitogénekre (például fitohemagglutininre) adott válasza viszont csökken [19]. Emberi thymectomia után az első 5 évben 20-30\%-kal csökken a mitogénekre adott válasz, de 15 évvel a mútét után már 50\%-kal $[20,21]$. Az autoreaktív nyiroksejtek mennyisége nő a periférián [22].

Számos kísérlet történt a thymus involúciójának lassítására hormonális beavatkozásokkal, ugyanis ismert, hogy a szteroid (elsősorban nemi) hormonok fokozzák a thymus involúcióját, míg a növekedési hormon csökkenti azt. Próbálkozások voltak melatonin alkalmazásával is. A legfrissebb hír a fibroblastnövekedési faktorról (FGF2l) szól, amely a májban és a thymusban egyaránt termelődik és amelynek mennyisége az étrend megszorításával növelhetô. Ez csökkenti a lipidlerakodást, növeli a T-sejtek kibocsátását és a naiv T-sejtek számát az öregedő egérben [23].

\section{A tobozmirigy-thymus kapcsolatok}

A tobozmirigy újszülöttkori kiirtása patkányban éppúgy az immunrendszer összeomlásához és wasting disease- 
hez vezet [24-27], mint a thymus eltávolítása egérben [4]. Ez hívta fel a figyelmet arra, hogy a tobozmirigy a thymus szabályozója, és ezt a több mint 40 éve általunk tett első megfigyelést [24, 27] számos újabb adat támasztotta alá. Azóta az is kiderült, hogy a tobozmirigy rendkívül sokoldalú (antioxidáns, gyökfogó, gyulladásgátló, de legfőképpen napi ritmust szabályozó) hormonja, a melatonin tartja fenn a kapcsolatot a tobozmirigy oldaláról, azonban a thymusban termelődő hormonok is hatnak a tobozmirigyre, tehát a szabályozás kétirányú, a melatonin dominanciájával [28]. A melatonin közvetlenül, akár in vitro is, de leginkább közvetve a thymuson keresztül az egész immunrendszert befolyásolja (immunmoduláló hatás), mert szabályozza a thymushormonok (timozin és timulin) termelődését [29] melatoninmembránreceptorokon keresztül, amelyek a thymusban jelen vannak. Ugyanakkor, ha a tobozmirigyet felnőtt patkányban kiirtják, gyors thymusinvolúció következik be [30]. Ha nagyon öreg tobozmirigyet implantálnak fiatal egér thymusába, ez gyors öregedést és korai pusztulást vált ki $[31,32]$.

A tobozmirigy éppúgy involúciónak van alávetve, mint a thymus, és a kor elörehaladtával fokozatosan (nókben a menopauza fellépésével) csökken a melatonin termelödése is $[33,34]$. Mivel a melatonin antioxidáns hatású is, szintjének csökkenése megengedi a káros oxidatív folyamatok előtérbe kerülését [35]. Az immunrendszer és természetesen ennek központi eleme, a thymus alapvetóen érintett a melatoninszint csökkenése által $[3,36]$, és a pinealis involúció miatt bekövetkező melatoninszint-csökkenés parallel fut a thymus involúciójával [37], a thymusban történő melatoninszintézis csökkenésével. A szabad gyökök elleni védekezés és az immunrendszer tevékenységének csökkenése kedvez a jellegzetesen időskori megbetegedések fellépésének [38], miközben pinealis peptidek adagolása csökkenti a mortalitást [39]. Egyes kutatók feltételezik a thymus és a tobozmirigy funkcionális egységét $[40,41]$, amit a thymus melatonintermelése is alátámaszt [42].

\section{Az öregedés és élettartam thymus általi szabályozása}

Az eddig elmondottakból nyilvánvaló, hogy a thymus immunoendokrin szerv, tehát mindkét szervrendszerbe besorolható. Mint endokrin szerv hormonokat termel, amelyek elsősorban a saját sejtjeire, illetve azokra a sejtekre hatnak, amelyek a szervből kikerülnek, ugyanakkor hormonok célpontja is. Mint az immunrendszer központi szerve, annak alapvető funkcióit határozza meg, ezáltal abszolút életfontos szerv. Az autoreaktív sejtek életben maradása ugyanis éppúgy a szervezet degenerációjához, majd halálához vezet, mint az idegenfelismerő sejtek hiánya.

A thymus involúcióját lehet a szervezet általános involúciója részjelenségének tekinteni, de ez félrevezető. A thymus ugyanis már sorvadni kezd, miközben a szer- vezet túlnyomó része még rapid fejlődést mutat, és időskorban a szerv involúciója sokkal kifejezettebb, mint a szervezet többi részéé. Ha azonban nem úgy tekintünk a thymusra, mint az öregedés áldozatára, hanem mint annak okozójára, akkor a jelenségek megmagyarázhatók. Ehhez azonban meg kell vizsgálnunk, melyek azok a thymusban, illetve az általa befolyásolt immunrendszerben zajló jelenségek, amelyek ezt a feltételezést indokolttá teszik.

A thymusban történik a csontvelőből oda kerülő lymphocyták negatív és pozitív szelekciója. Mint láttuk, ezek 95\%-a apoptózissal elpusztul és a megmaradó 5\% sejtjeinek többsége a sajátot nem ismeri fel idegenként. A megmaradó kevés hibás (autoagresszív) sejtet az ugyancsak a thymusban fejlődő Treg-sejtek nyomják el. Amíg tehát a thymus hibátlanul és teljes intenzitással múködik, addig a szervezet „tartalmának” fejlődése és fenntartása, valamint normális múködése lehetséges. Ez a fiatalkorra és a korai felnőttkorra jellemző. Ha a thymus múködése hibás vagy az életkor előrehaladtával elégtelenné válik, autoagresszív sejtek és erőtlen Treg-sejtek kerülnek a perifériára, így az offenzíva a saját sejtek ellen megindul. Ez természetesen - normális körülmények között - fokozatosan történik, mert ha hirtelen következnék be, gyors halálhoz vezethetne. Az autoreaktiv sejtek fokozatos felszaporodása és müködése azonban koptatja a sejteket és szöveteket, ami elosegiti a degenerativ betegségek fellépését is éppúgy, mint az immunitás idöskori gyengülése a fertözö betegségekét. A thymus fokozatos, de folyamatos involuciója tehát fokozatos szervezeti leépülést eredményez, mintegy az öregedést és élettartamot szabályozó ritmusadóként, pacemakerként müködve.

$\mathrm{Az}$ autoimmun betegségek fellépése egyaránt lehet a saját prezentáció gyengülésének és hiányának vagy a negatív szelekciót elkerülő sejtek megjelenésének (felszaporodásának) következménye. Ha az inzulingént még magzati korban „kiütik”, ez l-es típusú, autoimmun diabetes fellépéséhez vezet $[43,44]$. A szomatosztatinreceptor hasonló módon való elvesztése ugyancsak diabetest provokál [45]. Ennek alapján fel lehet tételezni, hogy egyéb hormonok prezentációjának hiánya is endokrin betegségek okozójává válik, sőt bizonyos nem hormonfehérjéknek a kritikus időpontban való hiánya vagy megkevesbedése autoimmun betegségekhez vezet. Ha feltételezzük, hogy a sajátot idegenként felismerő lymphocyták felszaporodása és a Treg-sejtek thymusinvolúcióval együtt járó megkevesbedése, illetve gyengülése autoimmun folyamatokat indít meg, akkor az öregedés egy thymuspezérelt lassú autoimmun folyamatként fogható fel. Egyes fontos sejtfunkciók autoimmunitás miatti kiesése az egész szervezetre általánosan, illetve egyes szervekre specifikusan visszahat, ami az öregedési folyamatot láncreakcióvá teszi.

Ha figyelembe vesszük, hogy a thymus képleteinek fogyatkozása a születés után rövid idővel megkezdődik, akkor az autoimmunitás hatása is ilyenkor indul. Ezt azonban túlkompenzálják a pozitív fejlődési folyamatok, 
amelyek egészen a serdülőkorig dominálnak. A kopás és újraképződés párhuzamosan fut, de a korai fázisban utóbbi elnyomja, illetve elfedi előbbi hatásait, tehát a jelenséget fejlődésként tartjuk számon. Ennek befejeztével, a serdülőkor végén, már a leépülési folyamatok dominálnak, és valóban ekkor válik észlelhetővé a thymus involúciója is. Ebben jelentős szerepet játszanak a pubertásban felszaporodó szteroid jellegú szexuálhormonok, amelyek thymusra kifejtett destruktív hatása közismert. A serdülökor tehát egyszerre hozza meg a gének továbbadásának lebetöségét és a továbbadó szervezet thymusinvolúció által történó fokozódó destrukcióját, ami biológiai szempontból értékelve természetesnek tünik.

Nem lehet véletlen, hogy napjainkban vált központi problémává az öregedés, mivel a kulturális evolúció haladása [46] lehetővé tette a szükséges biológiai kor megnyúlását. A biológiailag szükséges életkor alig több mint 30 év (természetes, „vad” körülmények között a tényleges életkor ma is ennyi), ami elégséges az utódgeneráció létrehozásához és annak önállóvá válásához. A gazdaságilag fejlett országokban tapasztalható jelenlegi további 40-50 év a szociális gondozás, a technika és az orvostudomány fejlődésének eredménye, amit a gének megengednek, de nem támogatnak, így nincs belekalkulálva a thymusélettartam szabályozószerepébe. A thymus involúciója tehát egyre kifejezettebbé válik, egyre inkább dominál az autoimmunitás általi leépülés és bekövetkezik a természetes (végelgyengüléses) halál.

A thymus által szabályozott autoimmunitás kezdetben nem okoz autoimmun betegségeket, hanem csak koptatja a sejteket és a sejt közötti állományt, ami legfeljebb kisebb funkciózavarokhoz vezethet, és ez még a problémamentes öregedés. Az autoagresszív sejtek tömeges megjelenése már autoimmun, illetve degeneratív betegségekhez (rheumatoid arthritis, lupus, Sjögren-szindróma éppúgy, mint arthrosisok, stroke, coronariakárosodás stb.) vezet, ami felgyorsítja a szervezet halállal végződő leépülését [47]. A folyamatot ronthatják külső tényezők, mint a szervezet túlterhelése, krónikus stressz, rossz életfeltételek és javíthatja mindezek elkerülése, miközben utóbbi nem állítja meg a thymusórát, csak csökkenti a negatív környezeti hatásokat.

Mint láttuk, a tobozmirigy postnatalis eltávolítása a thymus degradációjához és az immunrendszer összeomlásához vezet, és a felnőtt állat tobozmirigyének kiirtása fokozza az involúciót [30], míg melatoninkezelés akadályozza azt. A mirigy a thymushoz hasonlóan és azzal egyidejûleg sorvad és involúciója együtt jár hormonja, a melatonin szintjének csökkenésével [37]. Az állatkísérletek valószínűsítik a thymus tobozmirigy általi szabályozottságát. Feltételezhető tehát, hogy a tobozmirigy az öregedés és élettartam elsörendü szabályozója, aminek hatása a thymus és az immunrendszer müködésén keresztül valósul meg. A corpus pineale szabályozza a napi ritmust, a szezonális ritmust és valószínúleg az öregedési ritmust is. Mivel a felsőbb centrum a napi ritmus szabályozásában a suprachiasmaticus mag $[33,48]$, feltételezhető, hogy az öregedési ritmus szabályozásában is részt vesz. Mindenesetre van olyan emberen észlelt megfigyelés, amely szerint melatonin és thymuspeptidek adagolása növelte az élettartamot [39], azonban az SCN hatását nem vizsgálták. Ugyancsak elmaradt a thymus endokrin részének, azaz hormonjainak (a peptideknek) alapos hatásvizsgálata állatkísérletekben az autoimmunitásra és élettartamra. E hormonok azonban részt vesznek az immunelemek fenntartásában és szabályozásában, és az involúció ezek funkcióveszteségét is reprezentálja. A hámelemek involúciója tehát ki kell, hogy hasson az immunfunkciók múködésére is.

Az elmondottak bizonyitják, hogy a tobozmirigy-csecsemömirigy rendszer felelols az autoimmunitásért, és valószinüsitik, hogy ugyancsak felelós az öregedés és élettartam szabályozásáért. Ugyanakkor nincs bizonyíték arra vonatkozólag, hogy ezt kizárólagosan teszi, lehet, hogy más szervek, szervrendszerek is beleszólnak [49-51]. Feltételezhetjük azonban, hogy a rendszer az autoreaktív sejtek közreműködésével és azok szabályozásával önállóan is alkalmas az öregedés fellépésének és ritmusának kialakítására és az élettartam meghatározására.

Anyagi támogatás: A közlemény megírása anyagi támogatásban nem részesült.

A szerző a cikk végleges változatát elolvasta és jóváhagyta.

Érdekeltségek: A szerzőnek nincsenek érdekeltségei.

\section{Irodalom}

[1] Csaba, G.: Hormonal regulation: morphogenetic and adaptive systems. Biol. Rev. Camb. Philos. Soc., 1977, 52(3), 295-303.

[2] Manchester, L. C., Coto-Montes, A., Boga, J. A., et al.: Melatonin: an ancient molecule that makes oxygen metebolically tolerable. J. Pineal Res., 2015, 59(4), 403-419.

[3] Karasek, M.: Melatonin, human aging and age-related diseases. Exp. Gerontol., 2004, 39(11-12), 1723-1729.

[4] Miller, J. F.: The golden anniversary of the thymus. Nat. Rev. Immunol., 2011, 11(7), 489-495.

[5] Csaba, G.: Hormones in the immune system and their possible role. A critical review. Acta Microbiol. Immunol. Hung., 2014, 61(3), 241-260.

[6] Csaba, G.: The immuno-endocrine system: hormones, receptors and endocrine function of immune cells. The packed transport theory. Adv. Neuroimm. Biol., 2011, 1(1), 71-85.

[7] Jimenez-Jorge, S., Jimenez-Caliani, A. J., Guerrero, J. M., et al.: Melatonin synthesis and melatonin-membrane receptor (MT1) expression during rat thymus development: role of the pineal gland. J. Pineal Res., 2005, 39(1), 77-83.

[8] Szondy, Z., Garabuczi, É., Tóth, K., et al.: Thymocyte death by neglect: contribution of engulfing macrophages. Eur. J. Immunol., 2012, 42(7), 1662-1667.

[9] Nakagawa, ., Ohigashi, I., Nitta, T., et al.: Thymic nurse cells provide microenvironment for secondary $\mathrm{T}$ cell receptor $\alpha$ rearrangement in cortical thymocytes. Proc. Natl. Acad. Sci. U.S.A., 2012, 109(50), 20572-20577. 
[10] Guyden, J. C., Pezzano, M.: Thymic nurse cells: a microenvironment for thymocyte development and selection. Int. Rev. Cytol., $2003,223,1-37$.

[11] Sakaguchi, S., Wing, K., Miyara, M.: Regulatory T cells - a brief history and perspective. Eur. J. Immunol., 2007, 37(Suppl. 1), S116-S123.

[12] Reyes Garcia, M. G., García Tamayo, F.: The importance of the nurse cells and regulatory cells in the control of lymphocyte responses. BioMed Res. Int., 2013, 2013, Article ID 352414.

[13] Medawar, P. B.: The Nobel Lectures in immunology. The Nobel Prize for physiology or medicine, 1960. Immunological tolerance. Scand. J. Immunol., 1991, 33(4), 337-344.

[14] Aw, D., Silva, A. B., Palmer, D. B.: Immunosenescence: emerging challenges for an ageing population. Immunology, 2007, $120(4), 435-446$.

[15] Yung, R. L., Julius, A.: Epigenetics, aging and autoimmunity. Autoimmunity, 2008, 41(4), 329-335.

[16] Csaba, G.: The biological basis and clinical significance of hormonal imprinting, an epigenetic process. Clin. Epigenetics, 2011, 2(2), 187-196.

[17] Asano, M., Toda, M., Sakaguchi, N., et al.: Autoimmune disease as a consequence of developmental abnormality of a $\mathrm{T}$ cell subpopulation. J. Exp. Med., 1996, 184(2), 387-396.

[18] Bonomo, A., Kehn, P. J., Shevach, E. M.: Post-thymectomy autoimmunity: abnormal T-cell homeostasis. Immunol. Today, 1995, 16(2), 61-67.

[19] Pachciarz, J. A., Teague, P. O.: Age-associated involution of cellular immune function. I. Accelerated decline of mitogen reactivity of spleen cells in adult thymectomized mice. J. Immunol., 1976, 116(4), 982-988.

[20] Van de Griend, J. R., Carreno, M., Van Doorn, R., et al.: Changes in human $\mathrm{T}$ lymphocytes after thymectomy and during senescence. J. Clin. Immunol., 1982, 2(4), 289-295.

[21] Carnaud, C., Charreire, J., Bach, J. F.: Adult thymectomy promotes the manifestation of autoreactive lymphocytes. Cell. Immunol., 1977, 28(2), 274-283.

[22] Barrett, S. P., Toh, B. H., Alderuccio, F.: Organ-specific autoimmunity induced by adult thymectomy and cyclophosphamideinduced lymphopenia. Eur. J. Immunol., 1995, 25(1), 238-244.

[23] Youm, Y. H., Horvath, T. L., Mangelsdorf, D. J., et al.: Prolongevity hormone FGF2l protects against immune senescence by delaying age-related thymic involution. Proc. Natl. Acad. Sci. U.S.A., 2016, 113(4), 1026-1031.

[24] Csaba, G., Baráth, P.: Morphological changes of thymus and thyroid gland after postnatal extirpation of pineal body. Endocrinol. Exp., 1975, 9(1), 59-67.

[25] Csaba, G., Rados, I., Woblmuth, E.: Wasting disease and tetany following neonatal pinealectomy. Acta Med. Acad. Sci. Hung., 1973, 29(3), 231-240.

[26] Baráth, P., Csaba, G.: Histological changes in the lung, thymus and adrenal one and a half year after pinealectomy. Short communication. Acta Biol. Acad. Sci. Hung., 1974, 25(1-2), 123125 .

[27] Csaba, G.: The pineal regulation of the immune system: 40 years since the discovery. Acta Microbiol. Immunol. Hung., 2013, $60(2), 77-91$.

[28] Lin'kova, N. S., Poliakova, V. O., Trofimov, A. V., et al.: Influence of peptides from pineal gland on thymus function at aging. Adv. Gerontol., 2010, 23(4), 543-546.

[29] Molinero, P., Soutto, M., Benot, S., et al.: Melatonin is responsible for the nocturnal increase observed in serum and thymus of thymosin $\alpha_{1}$ and thymulin concentrations: observations in rats and humans. J. Neuroimmunol., 2000, 103(2), 180-188.

[30] Oner, H., Kus, I., Oner, J., et al.: Possible effects of melatonin on thymus gland after pinealectomy in rats. Neuro Endocrinol. Lett., 2004, 25(1-2), 115-118.
[31] Pierpaoli, W.: Neuroimmunomodulation of aging. A program in the pineal gland. Ann. N.Y. Acad. Sci., 1998, 840, 491-497.

[32] Pierpaoli, W., Bulian, D.: The pineal aging death program: life prolongation in pre-aging pinealectomized mice. Ann. N.Y. Acad. Sci., 2005, 1057, 133-144.

[33] Bubenik, G. A., Konturek, S. J.: Melatonin and aging: prospects for human treatment. J. Physiol. Pharmacol., 2011, 62(1), 13-19.

[34] Gursoy, A. Ү., Kiseli, M., Caglar, G. S.: Melatonin in aging women. Climacteric, 2015, 18(6), 790-796.

[35] Espino, J., Pariente, J. A., Rodriguez, A. B.: Oxidative stress and immunosenescence: therapeutic effects of melatonin. Oxid. Med. Cell. Longev., 2012, 2012, Article ID 670294.

[36] Karasek, M., Reiter, R. J.: Melatonin and aging. Neuro Endocrinol. Lett., 2002, 23(Suppl. 1), 14-16.

[37] Paltsev, M. A., Polyakova, V. O., Kvetnoy, I. M., et al.: Morphofunctional and signaling molecules overlap of the pineal gland and thymus: role and significance in aging. Oncotarget, 2016, 7(11), 11972-11983.

[38] Reiter, R. J.: The pineal gland and melatonin in relation to aging: a summary of the theories and of the data. Exp. Gerontol., 1995, 30(3-4), 199-212.

[39] Khavinson, V. Kh., Morozov, V. G.: Peptides of pineal gland and thymus prolong human life. Neuro Endocrinol. Lett., 2003, 24(3-4), 233-240.

[40] Polyakova, V. O., Lin'kova, N. S., Kvetnoy, I. M., et al.: Functional unity of the thymus and pineal gland and study of the mechanism of aging. Bull. Exp. Biol. Med., 2011, 151(5), 627630.

[41] Lin'kova, N. S., Poliakova, V. O., Kvetnoy, I. M., et al.: Characteristics of the pineal gland and thymus relationship in aging. Adv. Gerontol., 2011, 24(1), 38-42.

[42] Naranjo, M. C., Guerrero, J. M., Rubio, A., et al.: Melatonin biosynthesis in the thymus of humans and rats. Cell. Mol. Life Sci., $2007,64(6), 781-790$

[43] Geenen, V.: Thymus and type 1 diabetes: an update. Diabetes Res. Clin. Pract., 2012, 98(1), 26-32.

[44] Fan, ., Rudert, W. A., Grupillo, M., et al.: Thymus-specific deletion of insulin induces autoimmune diabetes. EMBO J., 2009, $28(18), 2812-2824$.

[45] Wang, X. P., Norman, M., Yang, J., et al.: The effect of global SSTR5 gene ablation on the endocrine pancreas and glucose regulation in aging mice. J. Surg. Res., 2005, 129(1), 64-72.

[46] Csaba, G.: Thoughts on the cultural evolution of man. Developmental imprinting and transgenerational effect. Riv. Biol., 2007, $100(3), 461-474$.

[47] Grolleau-Julius, A., Ray, D., Yung, R. L.: The role of epigenetics in aging and autoimmunity. Clin. Rev. Allergy Immunol., 2010, $39(1), 42-50$.

[48] Wu, Y. H., Swaab, D. F.: The human pineal gland and melatonin in aging and Alzheimer's disease. J. Pineal Res., 2005, 38(3), 145-152.

[49] Brown-Borg, H. M.: The somatotropic axis and longevity in mice. Am. J. Physiol. Endocrinol. Metab., 2015, 309(6), E503-E510.

[50] Atwood, C. S., Bowen, R. L.: The reproductive-cell cycle theory of aging: an update. Exp. Gerontol., 2011, 46(2-3), 100-107.

[51] Hirokawa, K., Utsuyama, M., Kikuchi, .: Trade off situation between thymus and growth hormone: age-related decline of growth hormone is a cause of thymic involution but favorable for elongation of lifespan. Biogerontology, 2016, 17(1), 55-59.

(Csaba György dr., Budapest, Pf. 370, 1445 e-mail: csagyor@dgci.sote.hu) 